\title{
UNLINKED CONTROL OF MULTIPLE GLUCOCORTICOID-INDUCED PROCESSES IN HTC CELLS
}

\author{
E. Brad THOMPSON ${ }^{*, 1}$, Darryl K. GRANNER ${ }^{2}$, Thomas GELEHRTER ${ }^{3}$, \\ Jeanne ERICKSON ${ }^{3}$ and Gordon L. H $\Lambda$ GER ${ }^{4}$ \\ ${ }^{1}$ Laboratory of Biochemistry, National Cancer Institute, NIH, 9000 Rockville Pike, Bethesda, \\ MD 20205, ${ }^{2}$ Department of Medicine and Biochemistry, University of Iowa College of \\ Medicine and Veterans Administration Hospital, Iowa City, IO 52242, ${ }^{3}$ Department of \\ Internal Medicine and Human Genetics, University of Michigan Medical School, \\ Ann Arbor, MI, and ${ }^{4}$ Laboratory of Tumor Virus Genetics, National Cancer Institute, \\ NIH, 9000 Rockville Pike, Bethesda, MD 20014 (U.S.A.)
}

Received 3 April 1979; accepted 20 June 1979

HTC cell variants chosen for their lack of tyrosine aminotransferase (EC 2.6.1.5) (TAT) induction by glucocorticoids were tested for interrelated effects on other glucocorticoid responses: TAT induction by dibutyryl cyclic AMP (dBcAMP) \pm dexamethasone, glutamine synthetase (GS) induction, cyclic nucleotide phosphodiesterase (PDE) suppression, inhibition of $\alpha$-aminoisobutyric acid (AIB) uptake, inhibition of plasminogen activator (PA), and induction of mouse mammary tumor virus (MTV). Loss of TAT induction by steroid was accompanied by loss of TAT induction by dBcAMP and of PDE suppression by steroid. In addition, subclones of MTV-infected cells were examined for the effect of the virus on glutamine synthetase (GS) and TAT induction. The virus had no effect on their induction in wild-type cells and no effect on GS induction in the variants. One MTV-infected subclone from a TAT variant, however, showed significant return of TAT induction.

Keywords: glucocorticosteroids; HTC cells; cell clones; mammary tumor virus; coordinate control; amino acid uptake; cAMP phosphodiesterase; glutamine synthetase; tyrosine aminotransferase; plasminogen activator.

Glucocorticoids affect many apparently unrelated biological processes in various cells, ranging from inhibition of cell growth and cell lysis in lymphoid populations to induction of specific peptides in a variety of cell types (Baxter and Forsham, 1972; Pitot and Yatvin, 1973; Thompson and Lippman, 1974; Thompson et al., 1977b). Sometimes in the same cell both inhibitory and inductive events take place, as for example in L cells or certain human leukemic cells, in which there is cell killing and induction of glutamine synthetase (Thompson et al., 1977b; Schmidt and

* To whom requests for reprints should be addressed. 
Thompson, 1979; Harmon et al., 1978). Little is known about the nature of the coordinate control of multiple, steroid-induced processes. Herein we utilize spontaneous HTC cell variants to study such control.

HTC cells are a line of tissue-culture cells derived from a rat hepatoma (Thompson et al., 1966); they are one of several such lines which have been employed extensively to study the physiology and pharmacology of hormone action (Potter, 1978). Glucocorticoids (up to $10^{-5} \mathrm{M}$ dexamethasone) in HTC cells do not affect cell growth but do inhibit several specific cell processes, while inducing others (Thompson et al., 1966; Granner et al., 1968; Ballard and Tomkins, 1969; Manganiello and Vaughan, 1972; Risser and Gelehrter, 1973; Yang et al., 1974; Carlson and Gelehrter, 1977; Crook et al., 1978). Virtually the entire domain of glucocorticoid-altered peptides in HTC cells recently has been defined (Ivarie and O'Farrell, 1978). A few years ago it was noted that upon cloning in non-selective conditions, the original lines of HTC cells showed a broad spectrum of TAT inducibility (Aviv and Thumpson, 1972). By direct repeated recloning of the least inducible clones from TAT wild-type cells, a number of HTC cell clones were derived which possessed basal levels of the enzyme but which were virtually noninducible (Thompson et al., 1977a). The nature of the altered control over the TAT gene in these cells is not known. However it was established that the TAT noninducible clones all contain glucocorticoid receptors which are able to translocate to the nucleus upon addition of steroid (Thompson et al., 1977a). These cells therefore represent a rare opportunity to search for interrelations between multiple steroid-controlled functions in subclones of a single cell line.

6 steroid-sensitive functions inherent to HTC cells were studied. The inducible functions studied were glutamine synthetase (Kulka et al., 1972; Arad et al., 1976; Crook et al., 1978), the steroid-dependent induction of TAT by analogs of cyclic AMP (Granner et al., 1968, 1975, 1977; Butcher et al., 1971; Van Rijn et al., 1974), and of course TAT induction by glucocorticoids. The functions inhibited by glucocorticoids which were chosen for study were cyclic AMP phosphodiesterase (Manganiello and Vaughan, 1972), the uptake of $\alpha$-aminoisobutyric acid (Risser and Gelehrter, 1973; McDonald and Gelehrter, 1977), and plasminogen activator production and release (Carlson and Gelehrter, 1977). In addition, both wild-type and non-inducible variant cells were infected with mouse mammary tumor virus, which is known to be an inducible function once integrated into the genome (Ringold et al., 1975, 1977, 1978). Subclones of infected cells were then tested for the influence of MTV infection on other inducible functions. The MTV-bearing TAT variant clones were also screened for MTV induction.

Several questions are addressed by these studies. Were all the functions coordinately lost in the TAT noninducible cells? If not, was there a pattern between clones or were losses of function random? Were the steroid receptors which are known to be in these cells undanaged? If one or more responses remained intact, it could be taken as presumptive evidence for at least part of the steroid receptors being intact. What were the effects of MTV on other induced functions and of the 
TAT inducible phenotype on MTV induction? Finally, what implications for the steroid-receptor model of steroid action are to be drawn from these cells?

\section{EXPERIMENTAL PROCEDURES}

\section{Cells}

The poorly inducing variants of HTC cells used in these studies are clones $268 \mathrm{E}$, M714H, M714I and 719C. These variants were derived from wild-type HTC cells by serial subclonings as follows: From HTC wild-type, 13 low-inducing clones were first obtained. Upon recloning one of these, two clones which induced little or not at all were identified - clones 271 and 268 . Clone $268 \mathrm{E}$ used in this study is a subclonc of clone 268. The clones of the 700 series are twice recloned from 271 . The letter $\mathrm{M}$ indicates that the cells were exposed to the mutagen nitrosoguanidine before subcloning. The TAT wild-type clone 921 was obtained from fully inducible cells, in experiments carried out simultaneously with those leading to the 700 series cells. Wild-type clone E $11_{4} 18$ was obtained independently by 3 serial subclonings. All these variants have been shown to be stable over a period of many months both in continuous culture and after having been stored in liquid nitrogen. They have been shown to possess basal TAT which is identical to that in wild-type cells on the basis of heat denaturation and reaction with antiserum specific to TAT. They do not contain enzymatically inactive, antigenically active TAT, and their enzyme is the same as that of wild-type with respect to rate of decay following inhibition of protein synthesis with cycloheximide. These cells all possess glucocorticoid receptors similar in amount to wild-type cells and with nuclear transfer properties the same as wild-type. The cells grow at the same rate as do wild-type cells. All these properties have been documented previously (Thompson et al., 1977a).

Cells were grown in either Improved Minimal Essential Medium - Zinc option prepared hy the NIH Media Unit, and supplemented with 5\% Fetal Calf Serum Richter et al., 1972); Eagle's Minimal Essential Mędium, $\alpha$ modification, supplemented with $10 \%$ fetal calf serum; or, for suspension culture, in Tricene-buffered Swim's medium as described by Gardner (1969) supplemented with 5\% calf plus $5 \%$ fetal calf serum. The cells' TAT phenotype was unaltered by these media and growth conditions.

\section{Assays of tyrosine aminotransferase and glutamine synthetase}

TAT was assayed by a modified version of the Diamondstone method as described previously (Thompson et al., 1970), except that the cell extract was prepared by sonication in $0.1 \mathrm{M}$ potassium phosphate buffer $\mathrm{pH} 7.6$, supplemented with $2 \times$ $10^{-4} \mathrm{M}$ pyridoxal phosphate and $5 \times 10^{-4} \mathrm{M} \alpha$-ketoglutarate. Cells were plated on $60-\mathrm{mm}$ Petri dishes at cell numbers known to give logarithmic growth in $24-48 \mathrm{~h}$ and all enzyme inductions were carried out under log growth conditions. For each induction experiment at least one TAT inducible clone was included as a positive control. Activity is expressed as mumole product formed per min per mg protein.

Glutamine synthetase was assayed on the basis of its glutamyl transferase activ- 
ity, by a modification of the method of Thorndike and Reif-Lehrer (1971). In preliminary experiments each component of the assay mixture was optimized, and the final reaction mix contained $260 \mathrm{mM}$ glutamine, $10 \mathrm{mM} \mathrm{MnCl}{ }_{2}, 42 \mathrm{mM}$ $\mathrm{Na}_{2} \mathrm{HAsO}_{4} \cdot 7 \mathrm{H}_{2} \mathrm{O}, 25 \mathrm{mM}$ sodium citrate, $0.1 \mathrm{mM}$ ADP, and $25 \mathrm{mM} \mathrm{H}_{2} \mathrm{NOH}$. $\mathrm{HCl}$. Cell monolayers were washed in situ by removing growth medium and then flooding the plate with $0.1 \mathrm{M}$ citrate buffer, $\mathrm{pH} 6.4$ at $0^{\circ}$, dislodged from the dish with a plastic policeman in $0.1 \mathrm{M}$ citrate buffer, collected by centrifugation at $600 \mathrm{~g}$ for $5 \mathrm{~min}$, and resuspended in an appropriate volume of $25 \mathrm{mM}$ citrate buffer, $\mathrm{pH} 6.4$ at $0-4^{\circ}$. An extract was made with a probe sonicator $(10 \mathrm{sec}$ at setting No. 15 on Bronwill sonicator). The broken-cell preparation was centrifuged at $1200 \mathrm{~g}$ for $5 \mathrm{~min}$ and the supernatant was assayed in the linear range of the assay. The reaction was stopped by adding a mixture containing $0.7 \mathrm{~N} \mathrm{HCl}, 0.2 \mathrm{~N}$ trichloroacetic acid, and $10 \mathrm{~g} \mathrm{FeCl} 3 \cdot 6 \mathrm{H}_{2} \mathrm{O}$ per $100 \mathrm{ml}$ and vortexing immediately. After centrifuging at $1200 \mathrm{~g}$ for $5 \mathrm{~min}$ the supernatant fraction was read on a spectroptrotometer at $500 \mathrm{~nm}$ within $30 \mathrm{~min}$ of slopping the reaction. Proteins were determined (as throughout this paper) by the method of Lowry et al. (1951), with bovine serum albumin as a standard, and specific activity of the enzyme calculated.

\section{Measurement of $A I B$ transport}

Cells were collected in the logarithmic phase of growth and plated on acidwashed glass scintillation vials at $10^{6}$ cells per vial. Confluent cultures were rinsed with phosphate-buffered saline $\left(0.138 \mathrm{M} \mathrm{NaCl}, 2.7 \mathrm{mM} \mathrm{KCl}, 8.1 \mathrm{mM} \mathrm{Na}_{2} \mathrm{HPO}_{4}\right.$, and $1.47 \mathrm{mM} \mathrm{KH} \mathrm{PO}_{4}, \mathrm{pH}$ 7.4) (PBS) and incubated in serum-free Eagle's Minimal Essential Medium containing $0.1 \%$ bovine serum albumin and $0.02 \%$ calcium chloride for $16 \mathrm{~h}$. The medium was then replaced with fresh serum-free medium with or without $0.1 \mu \mathrm{M}$ dexamethasone. AIB transport was measured by incubating the monolayer for $10 \mathrm{~min}$ at $37^{\circ}$ with $0.8 \mathrm{ml}$ of fresh medium containing $0.5 \mathrm{mM}$ AIB and $0.25 \mu \mathrm{Ci} / \mathrm{ml}\left[{ }^{14} \mathrm{C}\right] \mathrm{AIB}$. After aspiration of the radioactive medium, the cell layers were rinsed 3 times with cold PBS and allowed to dry. The cells were solubilized by incubation in $0.6 \mathrm{ml} 1 \mathrm{~N}$ sodium hydroxide at room temperature overnight. $75 \mu \mathrm{l}$ of each lysate was taken for assay of protein, and the remaining lysate was neutralized with $2 \mathrm{~N} \mathrm{HCl}$ and assayed for radioactivity after the addition of $5 \mathrm{ml}$ of ACS. The velocity of transport is expressed as nmoles AIB accumulated . $\mathrm{min}^{-1} \cdot \mathrm{mg}^{-1}$. Transport was corrected for background radioactivity by adding labeled AIB to a vial of cells, aspirating the medium immediately, and rinsing with cold PBS. Background counts were less than $1 \%$ of cell-associated counts in control cells.

\section{Measurement of plasminogen activator activity}

Confluent monolayer cultures on $60-\mathrm{mm}$ plastic culture dishes were incubated for $20 \mathrm{~h}$ at $37^{\circ}$ in serum-free minimal essential medium with or without $0.1 \mu \mathrm{M}$ dexamethasone. After aspirating the medium, the cell layers were rinsed twice with PBS at $0-4^{\circ}$ and the cells lysed by incubation for $5 \mathrm{~min}$ at room temperature with 
$0.5 \mathrm{ml}$ of $0.2 \%$ Triton-X 100 . The cells were scraped with a rubber policeman and transferred to a test tube along with an additional $0.5 \mathrm{ml}$ of the Triton solution. The lysates were passed through a Pasteur pipet to break up cell clumps and stored at $-20^{\circ}$ until they were assayed. Thawed lysates were clarified by centrifugation for $5 \mathrm{~min}$ at $36000 \times \mathrm{g}$. The supernatant fractions were then diluted to $0.5 \mathrm{mg}$ protein $/ \mathrm{ml}$ in $0.2 \%$ Triton and $0.2-\mathrm{ml}$ portions $(0.1 \mathrm{mg}$ protein) were assayed for PA activity by solubilization of ${ }^{125} \mathrm{I}$ fibrin as described by Strickland and Beers (1976).

\section{Cyclic nucleotide phosphodiesterase}

PDE was assayed after conversion of the product, $5^{\prime}$-AMP, to adenosine by snake venom $5^{\prime}$-nucleotidease (Thompson et al., 1974). The assay mixture consisted of 83 $\mathrm{mM}$ glycine buffer, pII 8.5 , with $28 \mathrm{mM} \mathrm{MgCl} 2 ; 150 \mu \mathrm{M}$ cyclic AMP (high $K_{\mathrm{m}}$ form) or $5 \mu \mathrm{M}$ cyclic AMP (low $K_{\mathrm{m}}$ form); $100 \mu \mathrm{g}$ of cell extract and $20000 \mathrm{cpm}$ of $\left[{ }^{3} \mathrm{H}\right]$ cyclic AMP (specific activity $30-50 \mathrm{Ci} / \mathrm{mmole}$ ) in a reaction volume of $300 \mu 1$. The reaction was initiated by the addition of enzyme and incubation was for 10 min at $30^{\circ} \mathrm{C}$. The reaction was terminated by the addition of $50 \mu 1$ of a solution containing $0.33 \mathrm{~N} \mathrm{HCl}, 1.2 \mathrm{mM}$ cyclic AMP and $6.7 \mathrm{mM} \mathrm{5}$-AMP, followed by heating to $100^{\circ}$ for $5 \mathrm{~min}$. Next was added $75 \mu \mathrm{l}$ of neutralizing solution $(0.5 \mathrm{M} \mathrm{Tris} \mathrm{Cl}$, $\mathrm{pH} 8.0$, final concentration $0.5 \mathrm{M} \mathrm{NaOH}$ ), the reactants were cooled to room temperature, and $150 \mu \mathrm{l}$ of Crotaline atrox venom $(1 \mathrm{mg} / \mathrm{ml}$ in Tris $\mathrm{Cl}, \mathrm{pH} 8.0)$ was added. After incubating for $30 \mathrm{~min}$ at $37^{\circ}, 0.1 \mathrm{ml}$ of $\left[8-^{14} \mathrm{C}\right]$ adenosine $(46-60$ $\mathrm{mCi} / \mathrm{mmole}$ ) containing $600 \mathrm{cpm}$ as tracer was added for estimating recovery. The sample was applied to a $3 \mathrm{ml}$ column of Sephadex QAE-25 and eluted with $2 \mathrm{ml}$ of distilled water. The effluent was collected, counted by liquid-scintillation technique, and the results were corrected for spillage from ${ }^{14} \mathrm{C}$, blanks and recovery.

\section{cAMP induction}

These experiments were carried out as described by Granner et al. (1977).

\section{Mouse mammary tumor virus infection and assay}

Variants of HTC cells were infected essentially as described by Vaidya et al. (1976). Cells were grown in complete medium supplemented with $5 \%$ fetal calf serum and $1 \mu \mathrm{g} / \mathrm{ml}$ dexamethasone. From $3 \times 10^{6}$ to $2 \times 10^{7}$ sub-confluent cells were then exposed to MTV derived from the $\mathrm{M}_{\mathrm{m}} 5 \mathrm{mt} / \mathrm{C}_{1}$ cell line at a multiplicity of approx. $1 \times 10^{5}$ particles/cell (determined by elcctron microscopy) in the presence of $5 \mu \mathrm{g} / \mathrm{ml}$ polybrene. After $2-5 \mathrm{~h}$, viruses were removed and growth continued in complete medium for $25 \mathrm{~h}$. Cells were then trypsinized and cloned by the end-point dilution method.

Approx. 75 independently-derived clonal lines were expanded in the presence of $1 \mu \mathrm{g} / \mathrm{ml}$ dexamethsone. Cells were collected by trypsinization, washed with PBS and lysed by gentle honogenization in the presence of $4 \%$ sodium lauryl sarcosinate and $0.1 \mathrm{M}$ Tris- $\mathrm{HCl}, \mathrm{pH} 7.9$, at $0^{\circ} \mathrm{C}$. An equal weight-volume of $\mathrm{CsCl}$ was added and dissolved by brief warming. This solution was layered over a $1 / 4$ volume cushion 
of $\mathrm{CsCl}(\rho=1.71)$ in $0.02 \mathrm{M}$ Tris $7.2,0.01 \mathrm{M}$ EDTA. This solution was centrifuged at $100000 \times \mathrm{g}$ for $16 \mathrm{~h}$. DNA was collected from the center of the gradient, the remainder of the gradient discarded, and RNA was isolated from the pellet by phenol extraction. The presence of MTV-specific RNA in the total RNA preparation was determined by conventional $\mathrm{C}_{\mathrm{r}} \mathrm{t}$ analysis with MTV-specific ${ }^{3} \mathrm{H}$-cDNA.

\section{Materials}

The $\alpha$-modified Minimal Essential Medium of Eagle was obtained from Flow Laboratories. Swim's 77 Spinner medium came from Grand Island Biological Co. Sera were obtained from Grand Island Biological Co., North American Biologicals, and St. Louis Serum Co. Fibrinogen was purchased from Cal Biochem, thrombin from Parke-Davis, and ${ }^{125} \mathrm{I}$ fibrinogen from Abbott Laboratories. Dexamethasone was a generous gift from Merck and Company. $\left[{ }^{14} \mathrm{C}\right] \mathrm{AIB}$ (spec. act. $9 \mathrm{mCi} / \mathrm{mmol}$ ) was purchased from New England Nuclear, and ACS from Amersham/Searle. Dibutyryl cAMP was obtained from Boehringer-Mannheim Corp. Venom was obtained from Ross Allen's Reptile Institute, Silver Spring, Fla.

\section{RESULTS}

\section{Behavior of inherent inducible functions}

Little or no TAT induction occurs in the variants at any time after the addition of steroid for up to several days (Thompson et al., 1977a). The basic noninducible nature of TAT in the HTC variants is again demonstrated in Fig. 1. Cells were exposed for $24 \mathrm{~h}$ to $10^{-6} \mathrm{M}$ dexamethasone, under standardized conditions, collected and assayed for TAT activity. As the figure shows, TAT in wild-type clone 921 induced as usual, from a basal specific activity of 13 to an induced level of 78 , whereas TAT in the 3 variants changed but little from its basal activity. Shown on the same figure are the effects of dexamethasone on glutamine synthetase activity in these cells. Glutamine synthetase induction has been extensively studied in chick neural retina (Schwartz, 1972), L cells (Thompson et al., 1977b), HTC cells (Kulka et al., 1972; Arad et al., 1976), Sézary cells (Schmidt and Thompson, 1979), and CEM cells (Harmon et al., 1978). GS induction in HTC cells has been shown recently to be the result of a steroid-dependent increase in its rate of synthesis, to depend on RNA synthesis, and to compare in many other ways very closely with TAT induction (Crook et al., 1978). In the TAT wild-type clone 921, GS rises from a basal specific activity of approximately 1.2 to an induced level of 4.4 after $24 \mathrm{~h}$ in the hormone. Each of the variant clones also is clearly inducible for glutamine synthetase, and although the fold of induction varies somewhat, it is similar in magnitude to that of the wild-type clone. The time course of induction of glutamine synthetase activity was also investigated and found not to differ between variants and wild-type (data not shown). It is therefore immediately apparent that there is a dissociation between the noninducibility of TAT and the inducibility of glutamine 


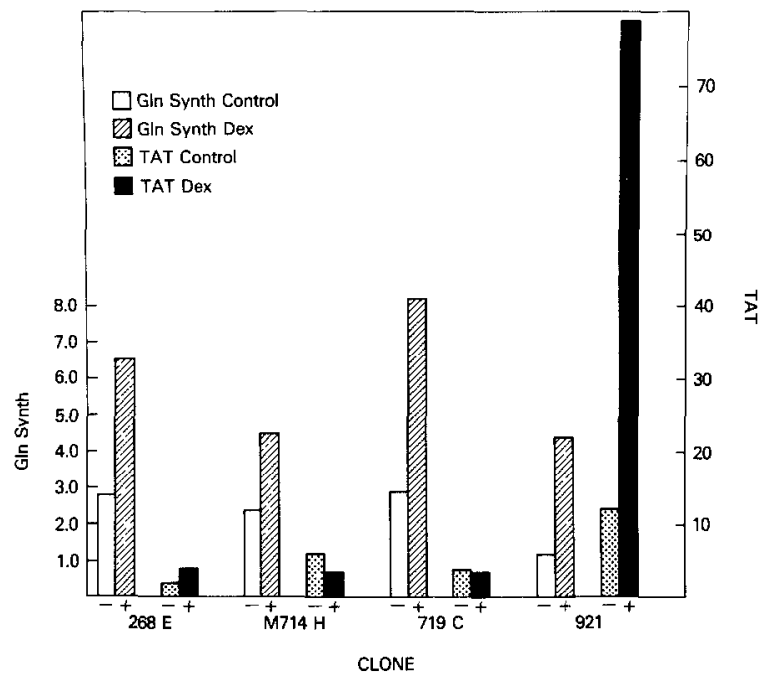

Fig. 1. Tyrosine aminotransferase (TAT) and glutamine synthetase (Glu Synth) specific activities in 4 clones of HTC cells. Cells were plated in $60-\mathrm{mm}$ tissue-culture dishes and allowed to reach logarithmic growth, whereupon the medium was exchanged for fresh growth medium containing either vehicle ( $1 \%$ ethanol, indicated by a -$)$, or $10^{-6} \mathrm{M}$ dexamethasone $(+)$. After a further 24-hı incubation, cells were harvested and assayed for each enzyme, as described in Experimental Procedures. Shown here are data from single samples for each bar; however they are representative of the results in many experiments. Duplicate assays on a given sample vary less than 10\%. (See also Table 1 and Thompson et al., 1977a.)

synthetase and that the two are not coordinately lost in these clones.

When the cells were examined for the combined effects of glucocorticoids and cyclic AMP analogues on TAT, however, a different result was obtained. Maximal induction of TAT hy cyclic nucleotides is glucocorticoid dependent (Granner, 1976; Granner et al., 1977). In the variants, pretreatment with glucocorticoid failed to render the cells sensitive to cyclic AMP induction of TAT. Table 1 summarizes experiments in which the effects of dexamethasone and cyclic nucleotide were compared in TAT wild-type and variant cells. Thus, the cells seem relatively unresponsive to two aspects of control over tyrosine aminotransferase. That they are not variants solely with respect to TAT, however, is shown by experiments on cyclic AMP phosphodiesterase activity.

\section{Behavior of inherent suppressible functions}

PDE activity, which has been shown to be diminished in HTC cells by treatment with dexamethasone (Manganiello and Vaughan, 1972), was studied in a number of ways, since the enzyme has not been as yet extensively characterized in these cells. In experiments to be published elsewhere, the effects of steroid on both the high $K_{\mathrm{m}}$ and low $K_{\mathrm{m}}$ forms of the enzyme in the wild-type clone E $11_{4} 18$ - time course, 
Table 1

Effects of $\mathrm{dBcAMP}$ and dexamethasone on variant $\mathrm{HTC}$ cell TAT

\begin{tabular}{llccc}
\hline Clone & Control & +dBcAMP & +Dex & +Dex +dBcAMP \\
\hline 921 & 12.9 & 17.3 & 40.8 & 66.2 \\
M714I (5) & $1.47 \pm 0.48$ & $1.33 \pm 0.21$ & $1.62 \pm 0.70$ & $1.81 \pm 0.70$ \\
M714H (5) & $1.92 \pm 0.35$ & $1.94 \pm 0.54$ & $1.98 \pm 0.82$ & $2.49 \pm 0.88$ \\
$719 \mathrm{C} \mathrm{(5)}$ & $1.98 \pm 0.66$ & $2.11 \pm 0.74$ & $2.37 \pm 0.78$ & $2.61 \pm 0.91$ \\
$268 \mathrm{E}(6)$ & $1.43 \pm 0.48$ & $1.25 \pm 0.41$ & $3.13 \pm 1.14$ & $3.34 \pm 1.10$ \\
\hline
\end{tabular}

Cells were plated in tissue-culture dishes, and during log growth were exposed for 2 days to $0.5 \times 10^{-6} \mathrm{M}$ dexamethasone (+Dex), for $4 \mathrm{~h}$ to $10^{-3} \mathrm{M}$ dibutyryl cAMP (+dBcAMP), or to dexamethasone for 2 days with dihutyryl-cAMP added during the final $4 \mathrm{~h}$ (+Dex $+\mathrm{dBcAMP}$ ). Control column represents cells incubated with no added hormone. A single experiment for wild-type clone 921 is shown; the data are the averages of assays on 4 dishes of cells. The average of 3-4 expts. is shown for each variant clone, \pm the standard deviation. The number of samples is shown in parenthesis. The figures given are TAT specific activity, in $\mathrm{mU} / \mathrm{mg}$ protein.

dose-response, enzyme kinetics - were all studied. Suppression of the enzyme began approx. $4 \mathrm{~h}$ after addition of steroid and reached a maximum by $24 \mathrm{~h}$. PDE suppression and the induction of TAT occurred at similar concentrations of dexamethasone. For example, $10^{-9} \mathrm{M}$ dexamethasone causes both a significant increase in TAT and a significant decrease in PDE activity. Maximal induction of TAT is seen at approximately $10^{-7} \mathrm{M}$ dexamethasone, and this concentration gives maximal inhibition of PDE activity. The inhibition of PDE activity by dexamethasone can be seen in cells grown in suspension or attached culture. With these data as background, we examined the variants for stervid effects on PDE. The experiment summarized in Table 2 illustrates typical results of treating 4 variant cell lines with $0.1 \mu \mathrm{M}$ dexamethasone for $24 \mathrm{~h}$. The wild-type clone shows suppression of PDE activity, but as can be seen there is no suppression of enzyme activity in any of the 4 variant clones tested. In no case was the $K_{\mathrm{m}}$ or $V_{\max }$ of the enzyme altered in the variants and time-course studies showed no effects of steroid on PDE activity in the variants at multiple time samplings between 0 and $48 \mathrm{~h}$. Likewise, very large concentrations $(12.5 \mu \mathrm{M})$ of dexamethasone tested in each variant failed to suppress phosphodiesterase activity, hence the lack of suppression is not merely due to altered sensitivity of the variant cells to the hormone.

The next inhibitory response studied was that of inhibition of $\alpha$-aminoisobutyric acid uptake. The uptake of AIB, a nonmetabolized amino acid analog, is diminished by $80-90 \%$ after $6 \mathrm{~h}$ incubation of HTC cells with dexamethasone. The response requires protein synthesis, and the concentration of steroid required for $50 \%$ response is the same as that for 50\% TAT induction or for $\sim 50 \%$ receptor occupancy (Risscr and Gclehrter, 1973; McDonald and Gelehrter, 1977). When the wildtype clone was compared with the variant clones for inhibition of AIB uptake the results of Fig. 2 were obtained. As the figure shows, and consistent with previous 
Table 2

Survey of cAMP phosphodiesterase activity in HTC cell variants

Low $K_{\mathrm{m}}(5 \mu \mathrm{M}$ cAMP $)$

(pmoles $\times \min \times \mathrm{mg}$ )

Control Dexamethasone

$(0.1 \mu \mathrm{M})$
High $K_{\mathrm{m}}(150 \mu \mathrm{M}$ cAMP $)$

(pmoles $X \min \times \mathrm{mg}$ )

Control Dexamethasone

$(0.1 \mu \mathrm{M})$

\section{Wild-type}

E-114-18

89

23

599

375

Variants

M714H

134

252

248

$268 \mathrm{E}$

376

206

397

246

630

602

574

856

1054

857

791

$719 \mathrm{C}$

1445

1429

Representative results in a typical experiment. Equivalent results were obtained for the above clones in 2-10 expts. each using duplicate assays on duplicate samples.

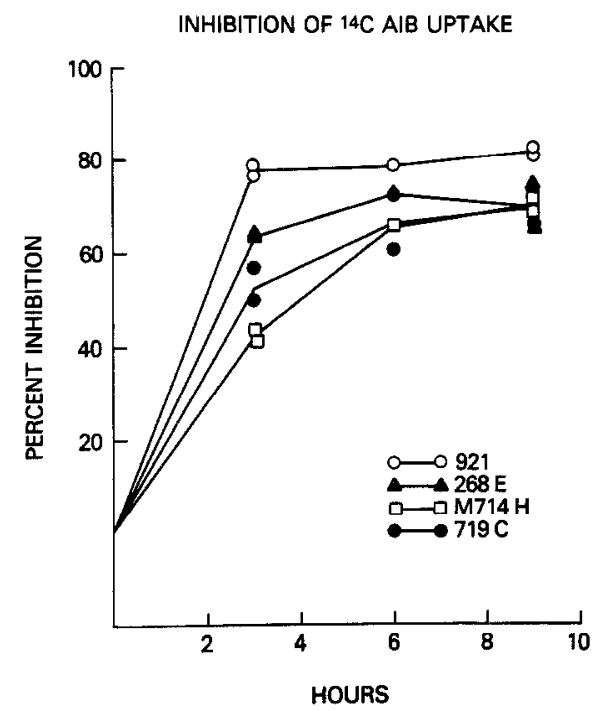

Fig. 2. Inhibition of initial rate of AIB transport by dexamethasone. The effect of dexamethasone on the initial rate of transport of AIB was measured in wild-type and variant cells as described in Experimental Procedures. Percent inhibition is plotted against time of exposure to the hormone. Each point represents an independent assay on a separate vial of cells. 
results in uncloned HTC cells, inhibition of AIB uptake in the wild-type cells has reached $80 \%$ at $4 \mathrm{~h}$ after the addition of steroid and remains at this level for the $9 \mathrm{~h}$ of the experiment. The uptake of the amino acid analogue was also inhibited in each of the 3 variant clones examined. Although in this experiment the rate and extent of inhibition in the variants were slightly less than that of the wild-type clone, in other experiments variants and wild-type were inhibited to the same extent. Certainly the overall. qualitative result is that uptake is inhibited in these clones.

The final inhibited function examined was plasminogen activator. This proteolytic activity is released from HTC cells, as it is from that of many transformed cells in culture. It has been shown that treatment of the cells with dexamethasone dramatically reduces both intracellular and extracellular activity (Carlson and Gelehrter, 1977; Carlson and Gelehrter, unpublished results). Fig. 3 shows the results of a

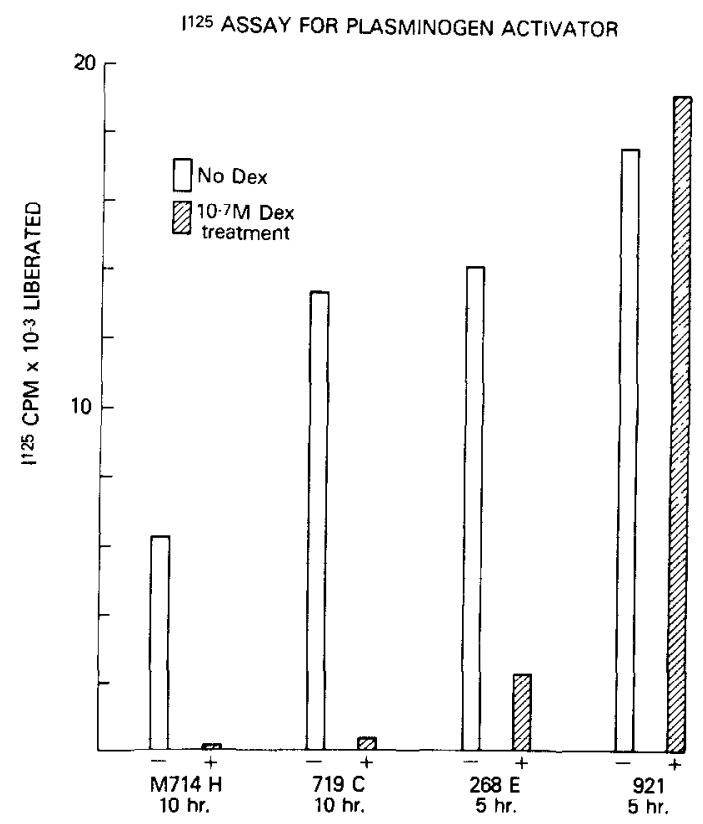

Fig. 3. Inhibition of intracellular plasminogen activator activity by dexamethasone. The cells were incubated for $20 \mathrm{~h}$ with (hatched bars) or without (open bars) $0.1 \mu \mathrm{m}$ dexamethasone, and intracellular plasminogen activator assayed as described in Experimental Procedures. The height of the bar represents the average of duplicate assays performed on each of duplicate culture dishes for each cell line. Because of higher endogenous rates of plasminogen activator activity, assays on lines $268 \mathrm{E}$ and 921 were carried out for $5 \mathrm{~h}$, whertas those on $\mathrm{M} 714 \mathrm{H}$ and $719 \mathrm{C}$ were carried out for $10 \mathrm{~h}$. The ordinate represents solubilized ${ }^{125} \mathrm{I}$ radioactivity above background. Duplicate assays varied no more than $3 \%$ from their average; duplicate samples varied no more than $6 \%$ from their average. 
comparison of the TAT variant clones with a wild-type clone for plasminogen activator activity. The TAT variant clones behaved as wild-type with respect to PA in this experiment, i.e., intracellular PA as measured by solubilization of ${ }^{125} \mathrm{I}$ fibrin was significantly reduced by prior treatment of the cells with dexamethasone. Remarkably, the TAT will-type clone 921 was found to behave as a variant with respect to PA; i.e., it was resistant to the inhibitory effects of the steroid on PA.

In summary, the results of these various tests in these variant clones show that the cells behave as wild-type cells with respect to glutamine synthetase induction, inhibition of plasminogen activator, and inhibition of AIB uptake. However, in addition to their failure to induce TAT by glucocorticoids, the variants were found to fail to suppress PDE activity and to lack the synergistic effect of cyclic nucleotide on TAT induction. Finally, the TAT wild-type clone 921 was found by chance to have a variant phenotype with respect to PA.

\section{MTV in wild-type and variant HTC clones}

Both variant HTC and wild-type cells were infected with MTV, subclones isolated and examined for any effects on GS or TAT. MTV expression was tested by $\mathrm{C}_{\mathbf{r}} \mathrm{t}$ analysis of cell RNA with MTV cDNA. In all 9 clones of infected variants tested, including examples from $268 \mathrm{E}, 719 \mathrm{C}$ and $\mathrm{M} 714 \mathrm{H}$, incubation of the cells

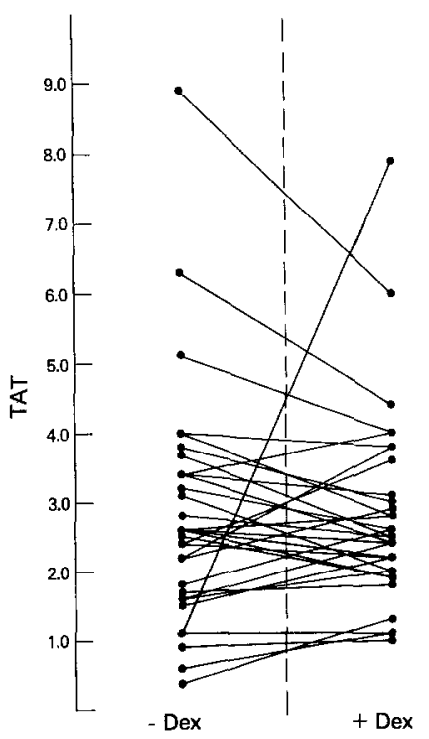

Fig. 4. Tyrosine aminotransferase specific activity (TAT) in 32 subclones of cells obtained from 3 clones of noninducible HTC variants infected with MTV. Represented are 7 infected subclones of clone $268 \mathrm{E}, 7$ of $\mathrm{M} 714 \mathrm{H}$, and 18 of $719 \mathrm{C}$. Each subclone was exposed to $10^{-6} \mathrm{M}$ dexamethasone in growth medium for $24 \mathrm{~h}$, controls were kept in medium only, and both were assayed for TAT as in Experimental Procedures. 
Table 3

Induction of TAT + GS in MTV infected HTC cells

Glutamine synthetase

$\begin{array}{llll}\begin{array}{l}\text { Number of } \\ \text { clones }\end{array} & - \text { Dex } & \text { +Dex } & \text { Fold induction }\end{array}$

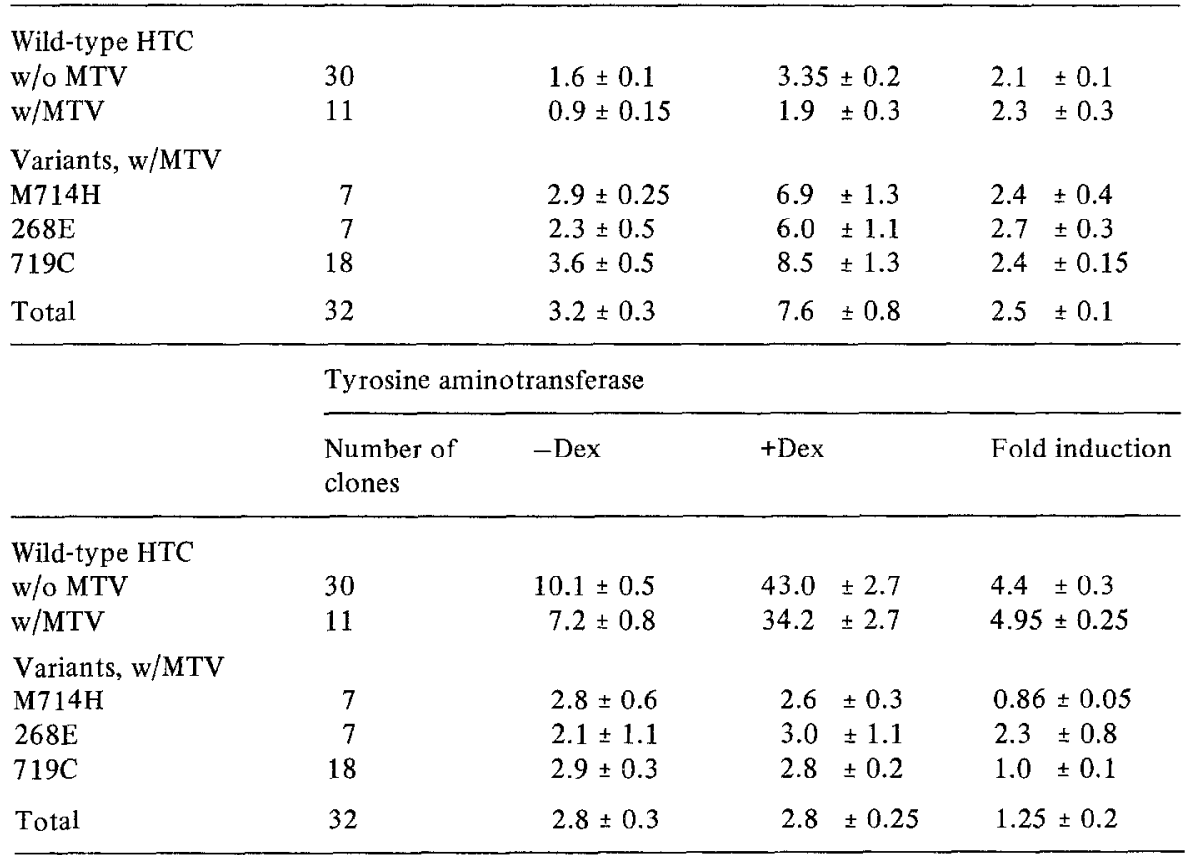

Specific activity of GS, $\mu$ g product $\cdot \mathrm{mg}^{-1}$ protein $\cdot \min ^{-1} \times 10^{2}$; specific activity of TAT mU/ mg protein, averages $\pm \mathrm{SE}$ are shown. Fold induction was calculated for each clone and averaged separately.

with $10^{-6} \mathrm{M}$ dexamethasone induced clear-cut increases of virus, as it did in most clones of infected wild-type cells (data not shown). The results of TAT and GS assays in the MTV infected clones and controls are shown in Table 3 and Fig. 4. When stock wild-type HTC cells were cloned without prior infection by MTV, they showed the same kind of broad spectrum of TAT inducibility previously described (Aviv and Thompson, 1972), and a narrower range of inducibility of GS. On the average, the fold induction of neither enzyme appears to have been affected by viral infection, although the average absolute levels of activity of both enzymes were slightly lower in the MTV-bearing clones. The distribution of inducibility of the enzymes was not skewed by the viral infection, and there were no individual ctones with remarkable alterations in induction (Thompson et al., in press). 
GS induction in the variants seemed unaffected by MTV. Both absolute levels and fold induction were similar to that of the uninfected parental clones, as demonstrated for example in Fig. 1. For the most part, the TAT phenotype of the variants also seemed unaffected by the presence of MTV. Among the 7 MTV-infected subclones of $268 \mathrm{E}$ tested, however, one showed significant induction of TAT. This infected clone stands out in Fig. 4 with a basal TAT level of $\sim 1$ rising to an induced level of $\sim 8$. Whether this is a single spontaneous revertant or is the direct result of MTV infection will be tested.

\section{DISCUSSION}

These studies with HTC variant cells are relevant to the basic nature of the events involved in steroid action. First, there was not coordinate loss of control of all steroid responses in these cells. If only TAT responses had been shown to be variant one might conclude that the cells possessed some alteration in expression of that gene only, but the fact that PDE suppression was lost as well suggests a more general effect, albeit one which does not extend to every steroid response. Either TAT induction and PDE suppression are functionally linked or both responses are the consequence of a single altered control step. Further evidence for the limited linkage between various functions is the finding that there is a reversal of the steroid resistance with respect to PA; that is, the TAT variants show wild-type phenotype for PA while a TAT wild-type clone is a resistant variant with respect to plasminogen activator. Other experiments have examined the relationship between TAT and PA in detail. HTC cells selected for PA production resistant to inhibition by steroids were assayed for TAT induction; all induced for TAT. As in the case of clone 921 reported here, no correlation was found between steroid regulation of PA and TAT inducibility (Carlson and Gelehrter, 1977; Carlson and Gelehrter, unpublished results). Thus our results do not support the model of a single steroidreceptor complex interacting with a single universally acting control element. Furthermore our data, though obviously not definitive, would be consistent with scattered vs. contiguous genes sensitive to steroid effects.

Second, since it is known from previous studies that these cells possess steroid receptors normal in quantity and capable of transfer into the nucleus in vivo and binding to the nuclei in vitro (Thompson et al., 1977a), we can conclude from the fact that glutamine synthetase and MTV remain inducible and that AIB uptake and PA are inhibited by steroid, that the cellular glucocorticoid receptors are at least partially functional. It has not been shown that receptors are required for each of these functions, but the weight of current evidence not only for glucocorticoids but for other steroid hormones, would suggest that that is the case. Alterations in groups of steroid responses in the presence of functional receptors indicate a complexity of control not often considered in current models of steroid action. Such control could be achieved through multiple subsets of receptors, through a variety 
of "adapter" molecules or through selective masking of potentially responsive genes. Most models of steroid--receptor interaction consider the receptor for each class of steroid receptors as a single molecule, i.e., the glucocorticoid receptor, the estrogen receptor, etc., but that is a description primarily based on the steroid-binding properties of these molecules. Various fractionation methods have suggested multiple molecular forms for receptors (Agarwal, 1977) but the data have not been compelling. In fact, very little is known of the physical properties of receptors which account for their specific interactions with chromatin (Yamamoto and Alberts, 1976). Thus each class of receptor could contain various subsets, all binding steroids identically but still showing heterogeneity with respect to their chromatin-binding sites. Alternatively, the heterogeneity of control seen in the variants observed here could occur through chromatin-acceptor molecules or through masking of specific gene sites. Various intranuclear proteins modulating steroid-receptor interactions with chromatin have been proposed. It has been suggested that these acceptors provide the cellular specificity for steroid-receptor action (O'Malley and Means, 1974; Puca et al., 1974; Spelsberg, 1976; Yamamoto and Alberts, 1976). Specialized subsets of such acceptors in a given cell could account for the specificity of control we have observed. Finally, control could take place by masking sites of interaction of the steroid-receptor complex with DNA sequences essential for induction, or by interfering with the posttranscriptional processing of steroidinfluenced gene products. Some of these alternatives can be tested, as, for example, by analysis for complementation groups or dominant/recessive properties in somatic cell hybrids. No complementation groups have been found in steroidresistant mouse lymphoid cells (Yamamoto et al., 1976) but that is probably because all such cells tested have been receptor mutants for a single response.

The third aspect of induction addressed by our studies is the relation between MTV induction and endogenous genes. Yamamoto et al. (1978) found that infection of a line of HTC cells with multiple copies of MTV often reduced the inducibility of TAT and GS together. Control of the two enzymes is not inextricably linked, however, as our noninfected variants show. With the HTC cells used here, we found no effect of the virus on induction of either enzyme, though the absolute activity of both enzymes was lowered somewhat. Our wild-type cells, however, differed from those used by Yamamoto et al. (1978) in showing a wide range of induction of TAT in uninfected subclones, as we had seen before (Aviv and Thompson, 1972); thus the differing results may stem from differing strains of parental HTC cells. Nevertheless, taken as they stand, our data do not show a shift of GS or TAT inducibility in MTV-infected wild-type HTC cells. In the TAT variant clones, MTV expression after infection behaved as usual, also speaking to a lack of association between the two. However, since these infected clones contained multiple copies of MTV, it is possible that some integrated at particular sites, were rendered noninducible by the lesion which affected TAT and PDE, while others at other loci, were induced as usual. As in the wild-type cells, GS was essentially unaffected by MTV in the variants. For the most part, TAT remained noninducible in the variants. 
One MTV infected clone, however, did show return of significant TAT induction. Further experiments will be necessary to see whether this was simply a coincidence, but perhaps this result represents an interaction between the MTV genome and elements regulating TAT expression.

\section{ACKNOWLEDGMENTS}

D.K. Granner is a Medical Investigator in the Veterans Administration and is supported by Veterans Administration Research Funds and by a National Institutes of Health Grant.

The authors wish to thank Ms. Charlotte Block for excellent technical assistance.

T.D. Gelehrter is supported by NIH Grant CA 22729 and by a Faculty Research Award from the American Cancer Society.

\section{REFERENCES}

Agarwal, M.K., Ed. (1977) Multiple Forms of Steroid Hormone Receptors, 1st edn. (Elsevier/ North-Holland, Amsterdam) $295 \mathrm{pp}$.

Arad, G., Freikopf, A., and Kukla, R.A. (1976) Cell 8, 95-101.

Aviv, D., and Thompson, E.B. (1972) Science 29, 1201-1202.

Ballard, P.L., and Tomkins, G.M. (1969) Nature (London) 224, 344-345.

Baxter, J.D., and Forsham, P.H. (1972) Am. J. Med. 53, 573-589.

Butcher, F.R., Becker, J.E., and Potter, V.R. (1971) Exp. Cell Res. 66, 321-328.

Carlson, S.A., and Gelehrter, T.D. (1977) J. Supramol. Struct. 6, 325-331.

Crook, R.B., Louie, M., Deuel, T.F., and Tomkins, G.M. (1978) J. Biol. Chem. 251, 61256131.

Gardner, R.S. (1969) J. Cell Biol. 42, 320-321.

Granner, D.K. (1976) Nature (London) 259, 572-573.

Granner, D., Chase, L.R., Aurbach, G.D., and Tomkins, G.M. (1968) Science 162, 1018-1020.

Granner, D.K., Sellers, L., Lee, A., Butters, C., and Kutina, L. (1975) Arch. Biochem. Biophys. $169,601-615$.

Granner, D.K., Lee, A., and Thompson, E.B. (1977) গ. Biol. Chem. 252, 3891-3897.

Harmon, J.M., Schnidt, T.J., and Thompson, E.B. (1978) J. Cell Biol. 79, 200a.

Ivarie, R.D., and O'Farrell, P.H. (1978) Cell 13, 41-55.

Kulka, R.G., Tomkins, G.M., and Crook, R.B. (1972) J. Cell Biol. 54, 175-179.

Lowry, O.H., Rosebrough, N.J., Farr, A.D., and Randall, R.T. (1951) J. Biol. Chem. 193, 265275.

Manganiello, V., and Vaughan, M. (1972) J. Clin. Invest. 51, 2763-2767.

McDonald, R.A., and Gelehrter, T.D. (1977) Biochem. Biophys. Res. Commun. 78, $1304-$ 1310.

O'Malley, B.W., and Means, A.R. (1974) Science 183, 610-620.

Pitot, H.C., and Yatvin, M.B. (1973) Physiol. Rev. 53, 228-325.

Potter, V.R. (1978) in: Morris Hepatomas, Mechanisms of Regulation, Eds.: H.P. Morris and W.E. Cross (Plenum, New York) pp. 59-87.

Puca, G.A., Sica, V., and Nola, E. (1974) Proc. Natl. Acad. Sci. (U.S.A.) 71, 979-983.

Richter, A., Sanford, K.K., and Evans, V.J. (1972) J. Natl. Cancer Inst. 49, 1705-1712. 
Ringold, G.M., Yamamoto, K.R., Tomkins, G.M., Bishop, J.M., and Varmus, H.E. (1975) Cell 6, 299-305.

Ringold, G.M., Yamamoto, K.R., Bishop, J.M., and Varmus, H.E. (1977) Proc. Nat1. Acad. Sci. (U.S.A.) 74, 2879-2883.

Ringold, G.M., Shank, P.R., and Yamamoto, K.R. (1978) J. Virol. 26, 93-101.

Risser, W.L., and Gelehrter, T.D. (1973) J. Biol. Chem. 248, 1248-1254.

Schmidt, T.J., and Thompson, E.B. (1979) Cancer Res. 39, 376-382.

Schwartz, R.J. (1972) Nature (New Biol.) (London) 237, 121-125.

Spelsberg, T.C. (1976) Biochem. J. 156, 391-398.

Strickland, S., and Beers, W.H. (1976) J. Biol. Chem. 251, 5694-5702.

Thompson, E.B., and Lippman, M.E. (1974) Metabolism 23, 159-202.

Thompson, E.B., Tomkins, G.M., and Curran, J.F. (1966) Proc. Natl. Acad. Sci. (U.S.A.) 56, $296-303$.

Thompson, E.B., Granner, D.K., and Tomkins, G.M. (1970) J. Mol. Biol. 54, 159-175.

Thompson, E.B., Aviv, D., and Lippman, M.E. (1977a) Endocrinology 100, 406-419.

Thompson, E.B., Norman, M.R., and Lippman, M.E. (1977b) Recent Prog. Horm. Res. 33, $571-615$.

Thompson, E.B., Granner, D.K., Gelehrter, T.D., and Hager, G.L. (1979) Proc. Cold Spring Harbor Symp. on Hormones and Cell Culture, in press.

Thompson, W.J., Booker, G., and Appleman, M.M. (1974) Methods Enzymol. 38, 205-212.

Thorndike, J., and Reif-Lehrer, L. (1971) Enzyme 12, $235 \cdots 241$.

Vaidya, A.B., Lasfargues, E.Y., Heubel, G., Lasfargues, J.C., and Moore, D.H. (1976) J. Virol. $18,911-917$.

Van Rijn, H., Bevers, M.M., Van Wijk, R., and Wicks, W.D. (1974) J. Cell Biol. 60, 181-191.

Yamamoto, K.R., and Alberts, B. (1976) Annu. Rev. Biochem. 45, 721 - 746.

Yamamoto, K.R., Gehring, U., Stampfer, M.R., and Sibley, C.H. (1976) Recent Prog. Horm. Res. 32, 3-32.

Yamamoto, K.R., Ivarie, R.D., Ring, J., Ringold, G.M., and Stallcup, M.R. (1978) In: Biochemical Actions of Hormones, 5, Ed.: G. Litwack (Academic Press, New York) in press.

Yang, S.S., Lippman, M.E., and Thompson, E.B. (1974) Endocrinology 94, 254-261. 